\title{
Production of $\alpha$-Amylase from Streptomyces sp. SLBA-08 Strain Using Agro-Industrial By-Products
}

\author{
Édilla Ribeiro dos Santos, Zozilene Nascimento Santos Teles, Núria Mariana Campos, \\ Diogo Angeli Jacinto de Souza, Aline Simões da Rocha Bispo and Rodrigo Pires do \\ Nascimento \\ Núcleo de Estudos em Microbiologia Aplicada; Centro de Ciências Agrárias, Ambientais e Biológicas; \\ Universidade Federal do Recôncavo da Bahia; Rua Rui Barbosa, s/n; 44380-000; Cruz das Almas - BA - Brasil
}

\begin{abstract}
Approximately 1.5 trillion tons are the estimated yearly biomass production, making it an essentially unlimited source of raw material for environmentally friendly and biocompatible products transformed by microorganism, specially fungi and actinomycetes. Several lignocellulosic residues, such as sisal waste and sugarcane bagasse contain starch in their structures which could become important sources for the production of amylases. This study evaluated the production of amylolytic enzymes using Streptomyces sp. SLBA-08 strain, isolated from a semi-arid soil, according to their ability to grow on soluble starch as the sole carbon source. The effect of the carbon source (sisal waste and sugarcane bagasse) on $\alpha$-amylase production was studied using submerged cultivations at $30{ }^{\circ} \mathrm{C}$. The highest level of $\alpha$-amylase activity corresponded to $10.1 \mathrm{U} . \mathrm{mL}^{-1}$ and was obtained using sisal waste (2.7\%) and urea $(0.8 \%)$ in submerged fermentation after 3 days of cultivation. The partial characterization showed the best $\alpha$ amylase activity at $50^{\circ} \mathrm{C}$ and $\mathrm{pH}$ 7.0. These results are of great importance for the use of sisal waste as a substrate for biotechnological proposes.
\end{abstract}

Key words: $\alpha$-amylases, sugarcane bagasse, sisal waste, Streptomyces sp.

\section{INTRODUCTION}

Lignocellulosic biomasses that contain starch in their structural composition are potential raw materials for the production of feedstock, biofuels and enzymes. These sources including wheat bran, wheat straw, corn, oat meal, rice, potato and cassava wastes, which contain $60-70 \%$ starch of their dried weight, and therefore represent a large source of biomass for fermentation (Nigam and Singh 1995). The utilization of agricultural byproducts and other natural compounds for growing microorganisms may constitute an interesting alternative towards enzyme production with lower costs. In Brazil, the amount of sugarcane bagasse comprises one of the largest cellulosic agroindustrial residues, and contains, approximately, $50 \%$ cellulose and $25 \%$ hemicellulose and lignin whereas the straw is composed of $37.4 \%$ cellulose, $30 \%$ hemicellulose and $18.5 \%$ lignin (Pandey et al. 2000). Both substrates have already been tested as main carbon source for the production of several enzymes including cellulases and xylanases.

However, others agro-industrial residues could be investigated as carbon source for enzymes production, such as sisal (Agaveae sisalana). Sisal (Agaveae sisalana Perr.) is a plant of high morphophysiological complexity and is a monocot. Agaveae sisalana contains amount $65 \%$

*Author for correspondence: rpn1978@gmail.com 
cellulose, $12 \%$ hemicelluloses, $10 \%$ lignin and $10 \%$ starch, and is an important cellulose source for the enzymatic process to produce biofuels. Sisal is the main hard fiber produced worldwide, corresponding to approximately $70 \%$ of commercial production of all fibers of this type. Brazil is the world's largest producer of sisal fiber, and has consolidated its position as market leader. Processed sisal fiber yelds about US\$ 80 million in exports for Brazil, and generates more than half a million jobs in its service chain, which begins with the maintenance activities of farming, harvesting, refining and processing of fiber and ends with industrialization and the making of handcrafts (Andrade 2010).

Bacterial $\alpha$-amylases are important and widely used enzymes. Their uses have grown for clinical and medicinal applications as well as analytical chemistry. Besides their use in starch saccharification they are also in the food, baking, brewing, detergent, textile, paper and distilling industries (Lin et al. 1998; Saxena et al. 2007). Actinomycetes are Gram-positive myceliumforming soil bacteria, able to produce and excrete a large variety of different antibiotics and enzymes. Many actinomycetes species have been studied for degradation of starch, hemicellulose, lignin and cellulose (Stamford et al. 2001; Nascimento et al. 2003; Bon et al. 2008; Nascimento et al. 2009).

Starch hydrolysis, catalyzed by $\alpha$-amylase, is one of the most important large scale uses of Actinomycetes in terms of enzymatic processes (Konsula and Kyrikiades 2004). The fact that some enzymes have the particular capacity to convert starch into shorter polymers of glucose units has made $\alpha$-amylase the subject of several studies in recent years for this kind of process (Gupta et al. 2003; Kandra 2003; Li et al. 2004).

The use of low cost residues as substrates in enzyme production is especially interesting for countries where agro-industrial residues are abundant (Gupta et al. 2003; Kandra 2003). Amongst the various agro-industrial by-products, sugarcane bagasse and waste sisal are produced in large amounts. Recently, various researchers have utilized sugarcane bagasse for different purposes, e.g. as substrate for bioethanol and enzyme production (Deepchand 1986; Dawson and Boopathy 2007). However, although sisal waste has not yet been reported as a substrate for enzyme production or some other biotechnological application, it could represent a very important alternative source for various biotechnological processes.

The aim of this work was selecting actinomycetes amylase-producers and to evaluate the $\alpha$-amylase production with the promising SLBA-08 strain, using agro-industrial by-products, such as sisal waste and sugarcane bagasse by submerged fermentation.

\section{MATERIAL AND METHODS}

\section{Selection of amylase-producing actinomycetes}

All the strains that were tested are deposited at the Actinomycetes Culture Collection of the Microbial Biotechnology Unit of Federal University of Recôncavo da Bahia (UFRB). For spore production, strains were cultured on malt extractyeast extract agar (Shirling and Gottlieb 1966), for 10 days, at $30^{\circ} \mathrm{C}$.

Petri dishes containing $\left(\mathrm{g} \mathrm{L}^{-1}\right)$ : soluble starch 10.0; yeast extract 1.0; agar 15.0 plus salts $\left(\mathrm{NaNO}_{3} 1.2\right.$;

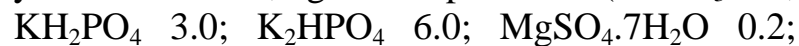
$\mathrm{CaCl}_{2} .2 \mathrm{H}_{2} \mathrm{O} \quad 0.05 ; \quad \mathrm{MnSO}_{4} .7 \mathrm{H}_{2} \mathrm{O} \quad 0.01$; $\mathrm{ZnSO}_{4} .7 \mathrm{H}_{2} \mathrm{O}$ 0.001), $\mathrm{pH} 7.0$, were spot inoculated, in duplicates. Amylase-producing strains were identified, after an incubation period of 10 days at $30{ }^{\circ} \mathrm{C}$, by addition of lugol solution $0.1 \%$ and observing a clearing zone surrounding the culture.

The actinomycete strain SLBA-08 was selected as promising starch-degrading and was isolated from a soil sample under Agaveae sisalana (sisal) plantation from the semi-arid region of Brazil, using the dilution plate technique. Based on $16 \mathrm{~S}$ rDNA sequencing and morphology of the spore chain, the strain was classified as belonging to the Streptomyces genus. Stock cultures were maintained on yeast extract-malt extract-agar plates and spores suspensions were prepared according to Hopwood et al. (1985) after cultivation $\left(28^{\circ} \mathrm{C} / 15\right.$ days $)$ in this same medium. Spores were maintained in $30 \%$ glycerol $(v / v)$ at $18^{\circ} \mathrm{C}$.

\section{Fermentation Conditions}

The actinomycete Streptomyces sp. SLBA-08 strain was cultivated in $250-\mathrm{mL}$ Erlenmeyer flasks containing $50 \mathrm{~mL}$ of a growth medium, as described above, supplemented with a carbon source (sisal waste or sugarcane bagasse) at different concentrations (Table 1), and urea as the nitrogen source, generating eight different runs. 
Flasks, inoculated with $50 \mu \mathrm{L}$ of a spore suspension $\left(1.61 \times 10^{8} \mathrm{CFU} \cdot \mathrm{mL}^{-1}\right)$, were incubated for 6 days at $30^{\circ} \mathrm{C} / 180$ rev.min ${ }^{-1}$ (orbital shaker New Brunswick Scientific Co., New Jersey, USA). Flasks were withdrawn every $24 \mathrm{~h}$ and their whole content filtered to separate cells from the supernatant. The contents of the flasks were centrifuged at $2,038 \mathrm{~g}$ at $4^{\circ} \mathrm{C}$ for $10 \mathrm{~min}$, filtered through a glass microfiber filter (Whatman GF/A), and the crude supernatants used for enzymatic assays.
The lignocellulosic biomasses were obtained from different sources. Sugarcane bagasse was obtained from sugar-ethanol plant in Amélia Rodrigues, BA, Brazil. The sisal waste was obtained from sisal farm in Valente, BA, Brazil. For fermentation studies, both residues were washed with distilled water, dried at $50^{\circ} \mathrm{C} / 48 \mathrm{~h}$ and milling.

All experiments were carried out in duplicate, and the results were expressed as average values. Regression analysis was carried out to help understand the significance of the values.

Table 1 - Media composition used for the different submerged fermentation conditions

\begin{tabular}{ccc}
\hline Culture Medium & Carbon Sources & Nitrogen Source \\
\hline 1 & Sugarcane Bagasse or Sisal Waste $(\% \boldsymbol{w} / \boldsymbol{v})$ & Urea $(\% \boldsymbol{w} / \boldsymbol{v})$ \\
2 & 0.8 & 0.3 \\
3 & 2.4 & 0.3 \\
4 & 0.8 & 1.3 \\
5 & 2.4 & 1.3 \\
6 & 0.5 & 0.8 \\
\hline
\end{tabular}

All media were supplemented with a salt mineral solution (see Material and Methods).

\section{Enzymatic Assays}

$\alpha$-Amylase activity was assayed by measuring the release of reducing sugars in a reaction mixture of $1.0 \mathrm{ml}$ of the crude supernatant and $1.0 \mathrm{ml}$ of $1 \%$ $(w / v)$ soluble starch (Sigma, MO, USA) solution in 0.05 mol. $\mathrm{L}^{-1}$ phosphate buffer (pH 6.9) incubated at $50^{\circ} \mathrm{C}$ for $20 \mathrm{~min}$ (Novozyme). Reducing sugars were assayed by the dinitrosalicylic acid (DNS) method (Miller 1959). One unit (U) of $\alpha$-amylase activity corresponded to $1 \mu \mathrm{mol}$ of glucose equivalent released per minute under the assay conditions (Bernfeld 1955).

\section{Influence of $\mathrm{pH}$ and temperature on enzyme activity}

Temperature profile for $\alpha$-amylase activity was determined by assaying activity at different reaction temperatures $\left(20^{\circ}\right.$ to $\left.100^{\circ} \mathrm{C}\right)$ in $50 \mathrm{mM}$ sodium phosphate buffer $(\mathrm{pH}$ 6.9). In the same way $\alpha$-amylase activity was assayed in different reaction buffers in $50 \mathrm{mM}(\mathrm{KCl}-\mathrm{HCl}$ for $\mathrm{pH} 2.0$; sodium citrate for $\mathrm{pH} 3.0-6.0$; phosphate for $\mathrm{pH}$ 7.0-8.0 and glycine- $\mathrm{NaOH}$ for $\mathrm{pH} 9.0-10.0$ ) at $50^{\circ} \mathrm{C}$ to determine the effect of $\mathrm{pH}$ on enzyme activity.

\section{RESULTS AND DISCUSSION}

\section{Selection of amylase-producing actinomycetes}

The screening data for $\alpha$-amylase-producing actinomycetes is shown in Table 2. Although three strains were prominent, among the nine actinomycetes that exhibited hydrolysis zones, the actinomycete SLBA-08 strain was chosen due to its good growth and sporulation characteristics.

Table 2 - Screening on agar plate of $\alpha$-amylase-producing actinomycetes, through hydrolysis zones on soluble starch medium.

\begin{tabular}{lccc}
\hline \multicolumn{1}{c}{ Soils and Bioms } & \multicolumn{2}{c}{ Amylase Activity Detected in Petri Dish } \\
\hline & - & + & ++ \\
Desert (semi-arid area) & 100 & 29 & 15 \\
Tropical forest (coast area) & 10 & 3 & 1 \\
Cerrado (mountain area) & 39 & 52 & 28 \\
\hline Total & $\mathbf{1 4 9}$ & $\mathbf{8 4}$ & $\mathbf{4 4}$ \\
\hline Hydrolysis zone: (-) negative; (+) weak (<2.0 cm diameter); (++) medium $(2.0<\mathrm{x}<3.0 \mathrm{~cm}$ diameter) $;(+++)$ strong $(>3.0 \mathrm{~cm}$ diameter)
\end{tabular}


This microorganism was isolated from a SemiArid Brazilian soil, collected from the Sisal Farm in Lage do Batata (Bahia, Brazil). This type of soil, that is quite similar to the African savanna and presents unique vegetation (cactus and agave), has not been studied for microbial biodiversity yet. Coelho and Drozdowicz (1978) described the Brazilian Cerrado as having soil very rich in actinomycetes and so far several strains showing proteolytic, cellulolytic and chitinolytic activities have been isolated from this habitat (Nascimento et al. 2005; Semêdo et al. 2001). Nascimento et al. (2003) reported a xylanase-producing actinomycete profile from different ecosystems (tropical forest, mangrove systems and cerrado). Santos and Martins (2003) reported several amylase-producing bacterial isolated from soil samples and the promising strain was identified as Bacillus sp. Agrawal et al. (2005) reported 33 bacterial colonies which showed a zone of clearance surround the microbial growth in starch medium, isolated from four different locations in IIT-Madras campus, Chennai, Índia.

\section{Enzymatic Production}

The time for cell growth and $\alpha$-amylase accumulation by the Streptomyces sp. SLBA-08 strain in submerged fermentations are shown in Figure 1 . The strain was able to produce amylases using sisal waste (Fig. 1A) and to a lesser extent, sugarcane bagasse (Fig. 1B), when supplemented with urea as the nitrogen source. Amylases levels varied within the range $1.2-10.1 \mathrm{U} \cdot \mathrm{mL}^{-1}$. The highest enzyme activity titer, $10.1 \mathrm{U} \cdot \mathrm{mL}^{-1}$, was observed after 3 fermentation-days in medium 6 , containing sisal waste $2.7 \%(\mathrm{w} / \mathrm{v})$ and urea $0.8 \%$ $(w / v)$, as shown in Fig. 1A. Experiments with sugarcane bagasse have shown best values for $\alpha$ amylase activity (4.20 U.mL $\left.{ }^{-1}\right)$ after 4 fermentation-days (Fig. 1B). The experiment was statistically significant at the $95 \%$ level of significance. Until now, there are no reports in the literature describing the use of sisal waste for enzyme production, and thus there are no sources for comparison and discussion of the results observed in this work.

Stamford et al. (2001) reported a high amylase activity (39.2 U.mL ${ }^{-1}$ ) for the Nocardiopsis sp. strain, an actinomycete isolated from yam bean, when starch and urea were used as substrates, after 3 fermentation-days. Santos and Martins (2003) observed high values for amylase activity (350 $\mathrm{U} . \mathrm{mL}^{-1}$ ) produced by Bacillus sp. when starch $1.0 \%(\mathrm{w} / \mathrm{v})$, yeast extract $0.5 \%(w / v)$ and peptone $1.0 \%(w / v)$ were used as substrates. Kathiresan and Manivannan (2006) detected a high amylase activity (150 U.mL ${ }^{-1}$ ) when maltose and peptone were used as substrate, after 4 fermentation days, by Penicillium fellutanum. Chakraborty et al. (2009), observed the maximum amylase production (4.5 U.mL ${ }^{-1}$ ) by marine Streptomyces sp. D1, after 10-days fermentation using sucrose and malt extract. The results presented in this work showed that the Streptomyces sp. SLBA-08 strain is a promising amylase producer and could be an important tool for biotechnology applications.

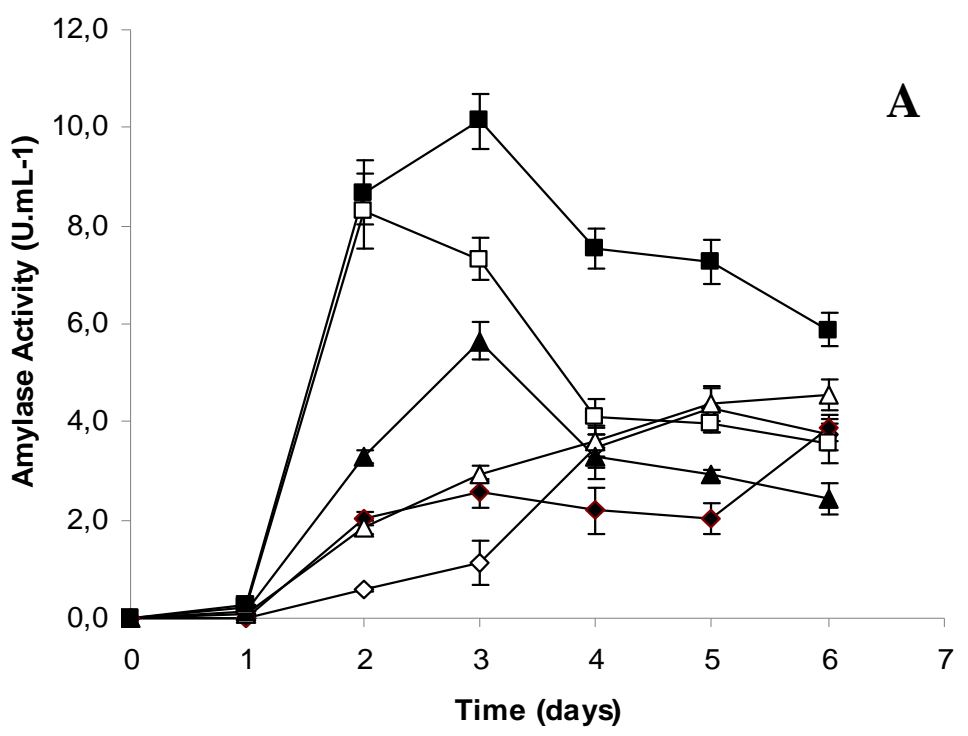




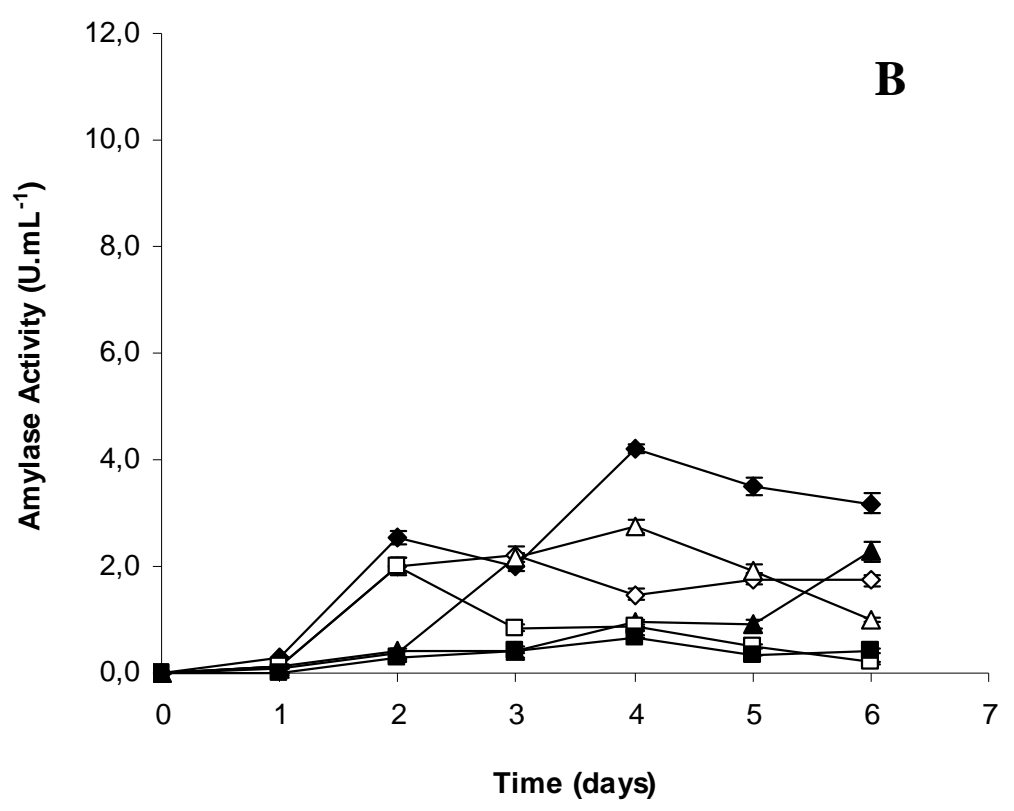

Figure 1 - Fermentation time for amylase production by Streptomyces sp. SLBA-08 strain at $28^{\circ} \mathrm{C}$ on culture media containing (A) sisal waste and (B) sugarcane bagasse as the carbon source in three different concentrations, and urea as the nitrogen source, in two different concentrations, as described in Table 1 . Medium $01(\diamond)$, Medium $02(\diamond)$, Medium $03(\triangle)$, Medium $04(\boldsymbol{\Delta})$, Medium $05(\square)$, Medium $06(\boldsymbol{\square})$.

Concerning the use of lignocellulosic residues as substrate for enzyme production, Figueira and Hirooka (2000) observed the production of amylases by Fusarium moniliforme and Aspergillus flavus using corn cob and corn straw. The maximum $\alpha$-amylase activity observed was 42.3 and 4,745.5 U.mL ${ }^{-1}$, after 10 fermentation days. Hernández et al. (2006) used brewery and meat processing wastewaters for amylase production by Aspergillus niger. The maximum activities detected were 70.3 and $60.1 \mathrm{U} \cdot \mathrm{mL}^{-1}$, respectively, after 3 fermentation-days. The use of lignocellulose biomass for enzyme production represents an alternative to reduce the production costs for biotechnological processes.

$\alpha$-Amylase present in supernatant from Streptomyces sp. SLBA-08 grown in sisal bagasse were significantly active in the temperature range tested (Fig. 2A). Maximal activities (above $75 \%$ relative activities) were observed within the range $40-60^{\circ} \mathrm{C}$ and activity levels of $30 \%$ were still detected at $80^{\circ} \mathrm{C}$. This value is similar or even higher than the optimal temperature reported by Chakraborty et al. (2009), for Bacillus strains. Asgher et al. (2007) observed an optimum of temperature at $70^{\circ} \mathrm{C}$ from moderately themophilic
Bacillus subtilis. The $\mathrm{pH}$ activity profiles, within the range 2-10, indicated that the maximum activity was observed at $\mathrm{pH}$ 7.0. However, the biocatalyst was able to present a good performance within the complete $\mathrm{pH}$ range, retaining 70\% activity still in $\mathrm{pH} 9.0$ (Fig. 2B). Also significant levels of activity (above $70 \%$ of relative activity) were detected between $\mathrm{pH} 5.0$ and 9.0. Concerning $\mathrm{pH}$ profile, the biocatalyst was able to present a good performance within the wide $\mathrm{pH}$ range, but the best results were in the neutral range, as observed by Negi and Banerjee (2009) in Aspergillus awamori. Chakraborty et al. (2009) detected a maximal amylase activity in $\mathrm{pH} 9.0$, presenting a good performance within the wide $\mathrm{pH}$ range $(7.0$ - 11.0) for Bacillus strain. These characteristics suggest a possible use for biotechnological processes.

The microorganism Streptomyces sp. SLBA-08 used in this study was able to grow and to produce $\alpha$-amylase using sisal bagasse and urea as sources of $\mathrm{C}$ and $\mathrm{N}$. The maximum $\alpha$-amylase activity detected was $10.1 \mathrm{U} \cdot \mathrm{mL}^{-1}$, on the third day of cultivation, when the salt mineral medium was supplemented with urea $0.8 \%(w / v)$ and sisal bagasse $2.7 \%(w / v)$. 

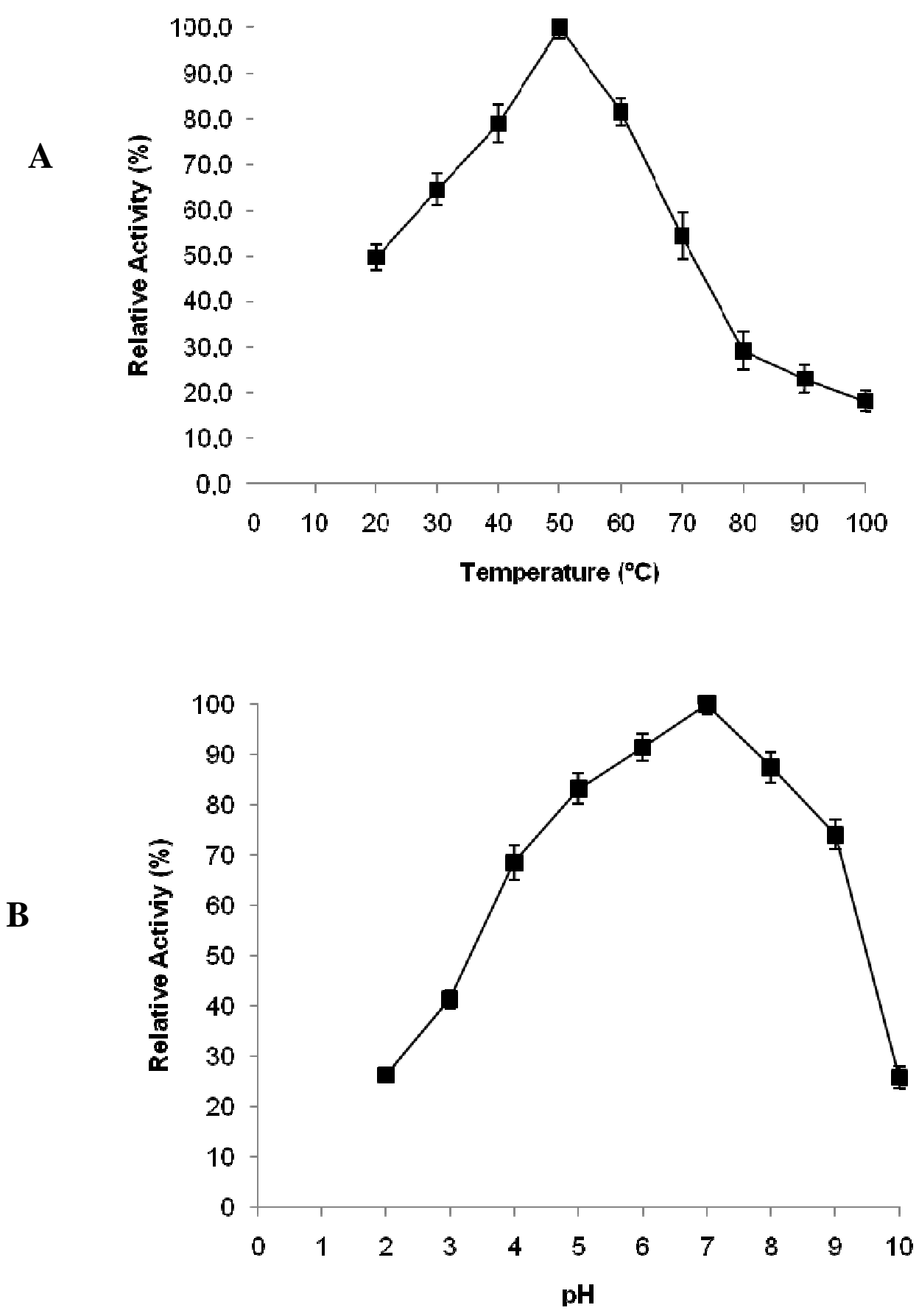

Figure 2 - Effect of temperature (at pH 6.9) (A) and $\mathrm{pH}\left(50^{\circ} \mathrm{C}\right)(\mathbf{B})$ of $\alpha$-amylase activity produced by Streptomyces sp. SLBA-08 grown on sisal bagasse $2.7 \%(w / v)$ and urea $0.8 \%(w / v)$. Residual activity is expressed as a percentage of the original activity.

These results showed the importance of searching for new biotechnological microbial sources in different ecosystems. Brazilian soils have have shown a great microbial biodiversity with different enzyme profiles, specially cellulases, xylanases, amylases and proteinases. The present work here reports for the first time the use of lignocellulosic residues, such as sisal waste or even sisal fiber as the carbon source for amylase production by an actinomycete strain, Streptomyces sp. SLBA-08. 
Sisal represents an alternative lignocellulosic source for enzyme production and biotechnological applications. Every year, many tons of sisal waste is generated and only a small amount is used as animal fodder.

\section{ACKNOWLEDGEMENTS}

The authors would like to thank Coodenação de Aperfeiçoamento de Pessoal de Nível Superior (CAPES), Conselho Nacional de Desenvolvimento Científico e Tecnológico (CNPq), Fundação de Amparo a Pesquisa do Estado da Bahia (FAPESB) for their financial support and Federal University of Recôncavo da Bahia (UFRB) for technical support.

\section{REFERENCES}

Agrawal M, Pradeep S, Chandraraj K, Gummadi SN. Hydrolysis of starch by amylase from Bacillus sp. KCA102: a statistical approach. Proc. Biochem. 2005; 40: 2499-2507.

Andrade W. Sisal Fiber in Brazil. Brazilian Fiber Publishing Web [cited 2010 October 04]. Avaialable from: http://www.braziliansisal.com.

Asgher M, Javaid Asad M, Rahman SU, Legge RL. A thermostable $\alpha$-amylase from moderately thermophilic Bacillus subtilis strain for starch processing. J. Food Eng. 2007; 79: 950-955.

Bernfeld P. Amylases $\alpha$ - and $\beta$-methods. Enzymol. 1955; 1: 149-158.

Bon EPS, Gottschalk LMF, Nóbrega R. Lignin peroxidase from Streptomyces viridosporus T7A: Enzyme concentration using ultrafiltration. Appl. Biochem. Biotechnol. 2008; 147: 391-400.

Chakraborty S, Khopade A, Kokare C, Mahadik K, Chopade B. Isolation and characterization of novel $\alpha$ amylase from marine Streptomyces sp. D1. J Mol Catal B: Enzymatic 2009; 58: 17-23.

Coelho RRR, Nascimento RP. Seleção de actinomicetos produtores de enzimas de interesse biotecnológico. In: editors Bon, E.P.S., Ferrara, M.A., Corvo, M.L. Enzimas em Biotecnologia: Produção, Aplicações e Mercado, $1^{\text {st }}$ edition Rio de Janeiro: Editora Interciência; 2008. 74-96.

Da Vinha FNM, Gravina-Oliveira MP, Franco MN, Macrae A, Bon EPS, Nascimento RP, Coelho RRR. Cellulase production by Streptomyces viridobrunneus SCPE-09 using lignocellulosic biomass as inducer substrate. Appl. Biochem. Biotechnol. 2011; 164 (3): 256-267.
Dawson L, Boopathy R. Use of post-harvest sugarcane residue for ethanol production. Biores. Technol. 2007; 98: 1695-1699.

Deepchand K. Economics of Electricity Production from Sugar Cane Tops and Leaves, a preliminary study. Int. Sug. Jnl. 1986; 88 (1055): 210-216.

Figueira ELZ, Hirooka Y. Culture medium for amylase production by toxigenic fungi. Braz. Arch. Biol. Technol. 2000; 43: 461-467.

Gupta R, Gigras P, Mohapatra H, Goswami VK, Chauhan B. Microbial $\alpha$-amylases: a biotechnological perspective. Proc. Biochem. 2003; 38: 1599-1616.

Hernández MS, Rodríguez MR, Guerra NP, Rosés RP. Amylase production by Aspergillus niger in submerged cultivation on two wastes from food industries. J. Food Enginee. 2006; 73: 93-100.

Kandra L. $\alpha$-Amylases of medical and industrial importance. J. Mol. Struct. (Theochem) 2003; 666667: 487-498.

Kathiresan K, Manivannan S. $\alpha$-Amylase production by Penicillium fellutanum isolated from mangrove rhizosphere soil. Afr. J. Biotechnol. 2006; 5 (10): 829-832.

Konsula Z, Liakopoulou-Kyriakides M. Hydrolysis of starches by the action of an $\alpha$-amylase from Bacillus subtilis. Proc. Biochem. 2004; 39: 1745-1749.

Miller L. Use of dinitrosalicylic acid reagent for determination of reducing sugar. Anal. Chem. 1959; 31: 426-428.

Nascimento RP, Marques S, Alves L, Gírio FM, Amaral-Collaço MT, Sacramento DR, Bon EPS, Coelho RRR. A novel strain of Streptomyces malaysiensis isolated from Brazilian soil produces high endo- $\beta$-1,4-xylanase titres. World J. Microbiol. Biotechnol. 2003; 19: 879-881.

Nascimento RP, D’Ávila-Levy CM, Souza RF, Branquinha MH, Bon EPS, Pereira Jr. N, Coelho RRR. Production and partial characterization of extracellular proteinases from Streptomyces malaysiensis AMT-3 isolated from a Brazilian cerrado soil. Arch. Microbiol. 2005; 184: 194-198.

Nascimento RP, Alves-Jr. N, Pereira Jr. N, Bon EPS, Coelho RRR. Brewer's spent grain and corn steep liquor as substrate for cellulolytic enzymes production by Streptomyces malaysiensis. Lett. Appl. Microbiol. 2009; 48: 529-535.

Negi S, Banerjee R. Characterization of amylase and protease produced by Aspergillus awamori in a single bioreactor. Food Res. Int. 2009; 42: 443-448.

Ningam P, Singh D. Enzyme and microbial systems involved in starch processing. Enzyme Microbial Technol. 1995; 17: 770-778.

Pandey A, Soccol CR, Nigam P, Soccol VT. Biotechnological potential of agro-industrial residues. I: sugar cane bagasse. A review. Biores Technol. 2000; 74 : 69-80. 
Santos EO, Martins MLL. Effect of the medium composition on formation of amylase by Bacillus sp. Braz. Arch. Biol. Technol. 2003; 46: 129-134.

Saxena RK, Dutt K, Agarwall L, Nayyar P. A highly thermostable and alkaline amylase from a Bacillus sp. PN5. Biores. Technol. 2007; 98: 260-265.

Semêdo LTAS, Linhares AA, Gomes RC, Manfio GP, Alviano CS, Linhares LF, Coelho RRR. Isolation and characterization of actinomycetes from Brazilian tropical soils. Microbiol. Res. 2001; 155: 259-266.

Shirling EB, Gottlieb D. Methods for characterization of Streptomyces species. Int. J. Syst. Bacteriol. 2966; 16: 313-340.
Soccol CR. Enzyme Technology. New Dehli, Asiatec Publishers Inc. 2005.

Stamford TIM., Stamford NP, Coelho LCBB, Araujo JM. Production and characterization of thermostable $\alpha$-amilase from Nocardiopsis sp. endophyte of yam bean. Biores. Technol. 2001; 76: 137-141.

Received: September 16, 2011; Revised: March 9, 2012; Accepted: July 19, 2012. 